\title{
Sustainable Development and Justice between Generations in Latvia. Case of IT Professionals
}

\author{
Svetlana Gribanova* \\ Turba University, Latvia
}

\begin{abstract}
The ideas of social justice between members of the same generation and between members of different generations are described in scientific literature as the main normative principles of sustainable development. Distribution of public resources between generations can be considered fair and honest, when each successive generation can expect the same care and benefits as the previous generation. But, in the modern world, it is almost impossible. Are there any intergenerational conflicts in Latvia connected with environmental and social justice? This question has become the main research issue of this study. The results of the study show that in Latvian society there is a certain understanding of environmental justice, as necessity to limit intensity of consumption in order to preserve the environment. In this issue, interests of all generations intersect, so environmental problems can be solved in society without intergenerational conflicts. Social justice issues are more complex for Latvian society. Even in high-income social groups, generational perceptions of how fairly the state redistributes public resources differ. This provokes a protest, which is expressed in unwillingness to pay taxes and justification of tax evasion.
\end{abstract}

\section{Introduction}

Justice between people of different generations is the main idea of sustainable development policy. It means that well-being of one generation should not be achieved by reducing opportunities for next generations [1].

Conflicts between generations are the most important social problem of modern society. According to many experts, intergenerational conflict has largely replaced class conflict, which was partially resolved with the help of social policy and social protection [2].

It is important to say that modern intergenerational conflicts differ from those in the past. In the 20th century, conflicts between generations affected the spheres of politics and culture. Today, these conflicts have moved into economic and environmental spheres, as they are connected with redistribution of public resources between generations, when wellbeing of one generation is created by means of another generation. That is, modern intergenerational conflicts arise from unequal distribution of benefits gained from social policy and economic development [3].

Inequality between generations in modern society is discussed as part of a larger social problem - the problem of sustainable development in conditions of limited environmental

* Corresponding author: svetlana.gribanova.p@gmail.com 
and economic resources [4]. Poverty reduction and economic growth come at the expense of environmental harm, which reduces opportunities for well-being of future generations. To solve economic problems connected with supporting the elderly, modern states spend much more money than they do to support the younger generations [5]. Such an unequal distribution of resources between generations can be considered as certain injustice. For sustainable development, not only goals but also means are important.

Justice issues play a very important role for sustainable development, as modern policy model is based on individual participation in public sphere. Therefore, functioning of social state depends on how much it is accepted by citizens [6].

The concept of sustainable development appeared in a post-industrial society with innovative economy, where knowledge is the main resource. In a post-industrial society, there are mechanisms that turn knowledge into economic resources. One of the most important mechanism for such transformations is information technology. It is information technology that allows modern society to develop in a social and economic direction [7].

In modern Latvian society, innovative economy is developing at a high rate. In 2018, Latvia took 39th place in the Global Innovation Index, and further development is possible through expanding and distributing creative IT professionals across the country [8]. Over the last five years, the number of IT professionals in Latvia has increased by $96 \%$. This is the fastest growing professional group. What's more, this professional group has more modernized values (in relation to all Latvian society). Therefore, justice ideas of this professional group are important for understanding possibility of sustainable development in Latvia in general.

Despite the fact that the field of information technology is quite new for Latvia, there are people of different generations among IT professionals. The question arises, to what extent representatives of different generations of IT professionals in Latvia differ in their ideas about fair distribution of resources. Are there any intergenerational conflicts in Latvia connected with environmental and social justice? This question has become the main research issue of this study.

\section{Research methodology}

One of possible approaches to the study of justice distribution in society is an approach that is based on analysis of attitudes and beliefs that exist in society [50]. At collective level, adoption of reforms and state policy depends on perception of justice principles in distribution of public resources. At individual level, acceptance of justice principles affects agreement of citizens to pay taxes and society's tolerance for tax evasion [9].

Distribution of social resources between generations can be considered fair and honest, when each subsequent generation can expect the same concerns, payments and living conditions as the previous generation. Problems occur only when there are no equal care and equal conditions, it is more a rule than an exception in the modern world [10].

Economic growth at the expense of environmental degradation can lead younger generations to choose to live and work in other countries to avoid paying taxes to government, which reduces their opportunities for a prosperous future. Redistribution of public resources in favor of older generations can make younger generations consider such offenses as tax evasion, receiving state benefits to which they don't have the rights acceptable for themselves.

To study intergenerational conflicts among IT professionals in Latvia, the following generations have been identified in this research:

- Generation of 1960-1970. Early X. In Latvia this generation was born and grown in conditions of strong communist ideology and economic problems [11], but at the same time, rapid technological development. They witnessed the expansion of the Soviet Union's 
influence in Eastern Europe and the increase of the USSR's global influence. According to Brown's research [12], this period was the most cynical in the whole history of communist countries. As the result, while the mechanism of state socialization emphasized the need for state support, informal socialization often emphasized importance of ability to exploit the system for own advantages $[13,14]$.

- Generation of 1971-1980. Transition generation. In Latvia, as in other Eastern European countries, members of this generation belong to so-called transition generation. The older members of transition generation were grown up during transition to democracy and market reforms. They witnessed a collapse of communist regimes and rapid political transformations [15].

- Generation 1980-1990. Millennials. In Latvia, as in other post-communist countries, members of this generation almost do not remember the communist regime, a new regime became a norm for them. They were socialized in conditions of transition from a command economy to a market economy, formation of Western values and humanistic ideology in society.

- Generation 1991 and younger. Z-generation. The youngest and most progressive generation. These people were grown up in conditions of rapid development of information technology. Their socialization took place when Latvia had already joined the EU. They felt more like citizens of the United Europe than citizens of national states. The values connected with self-realization, environmental protection are important for them. This generation will experience consequences of today's risks [16].

The selected generations of Latvian society were socialized in different historical periods, which could affect their ideas of justice. Differences in social experience can provoke conflicts between generations.

For collecting empirical data in this study, online questionnaire method was used. The questionnaire consisted of closed questions. The first part of the questionnaire considered social, demographic and qualification characteristics of employees in companies. The second part of the questionnaire was focused on the study of values, professional attitudes and political orientations. The survey was conducted in 2019. The sample size was 1,200 people. All respondents worked in the field of information technology in Latvian companies. $77 \%$ of the respondents were men, $23 \%$ - women.

The study tested the following hypotheses:

H1: Environmental Justice. Representatives of older generations are more likely to justify economic growth by harming the environment than younger generations.

$\mathrm{H} 2$ : Altruistic values. Representatives of younger generations are more likely than older generations to support charity, work as volunteers and selflessly help those in need.

H3: Social justice. There are generational differences in justification of offenses against the government. Representatives of younger generation are more likely to justify such offenses as tax evasion, while the older generation is more likely to justify the use of benefits they have no rights to.

\section{Research results}

To test the environmental justice hypothesis, the following variables were used:

Question 1: There are two opinions about ecology and economic growth. Which one is closer to your point of view?

- Priority should be given to protection of the environment, even if it will somewhat delay economic growth and lead to job losses.

- Priority should be given to economic growth and new jobs, even if it does some harm to the environment. 
Question 2: Below are descriptions of people. Please note how much each of the descriptions is like or not like you: For this person, care for the environment and ecology is important.

- Very much like me

- Looks like me

- Something like me

- A little like me

- Not like me

- Not at all like me

Generational differences in answers to these questions were determined using the chisquare test.

Figure 1 shows distribution of the answers of the respondents from different generations of IT professionals to the first question.

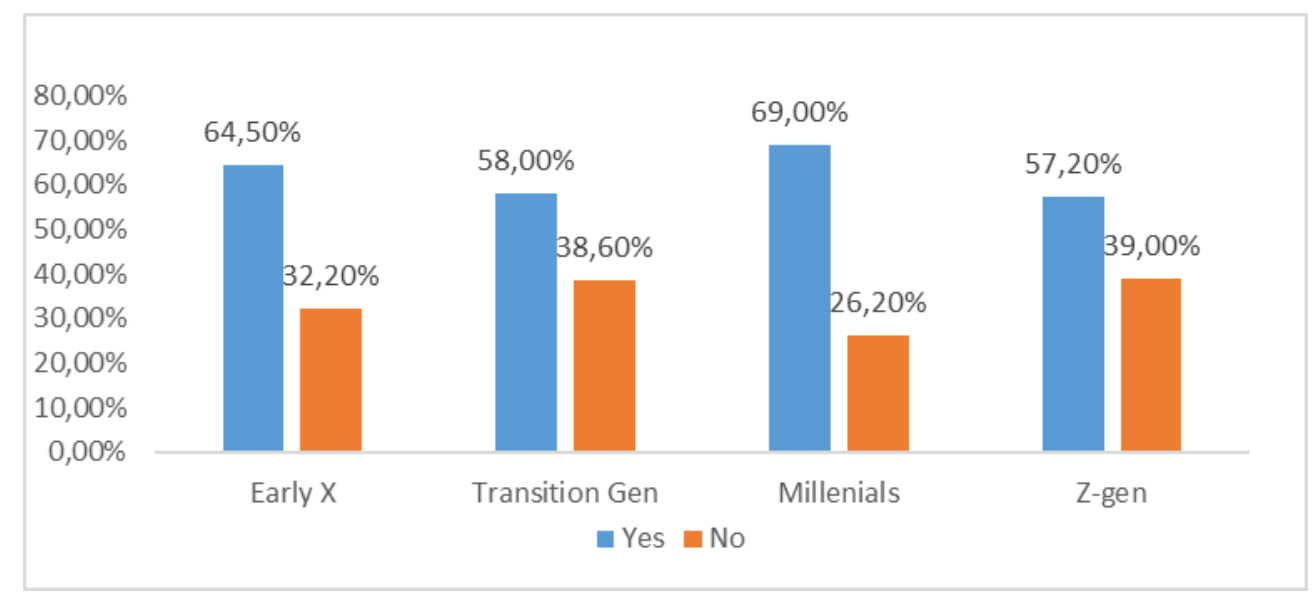

Fig. 1. Priority should be given to protection of the environment, even if it will somewhat delay economic growth and lead to job losses.

Despite visible differences presented in Figure 1, the results of the chi-square test show that there are no differences between generations in this question (the significance of the chi-square test is 0.586 ). Representatives of all generations are more likely to agree that priority of economic development should not be economic growth, but concern for the environment. Such attitude to ecology shows importance of postmodern values for Latvian IT professionals. Absence of intergenerational conflicts in this issue shows that in this professional group there is a generational consensus in which it is necessary to limit consumption in society, that a consumer society can bring irreparable harm to the environment, which will worsen the quality of life of future generations.

The second question about ecology is more personal. It is not about society itself, but about personal qualities of the respondents. Distribution of the answers to this question among respondents of different generations is shown in Figure 2. The obtained results show that environmental care is a significant personal characteristic of IT professionals in Latvia, regardless of their generation. The significance of chi-square test is 0.496 . 


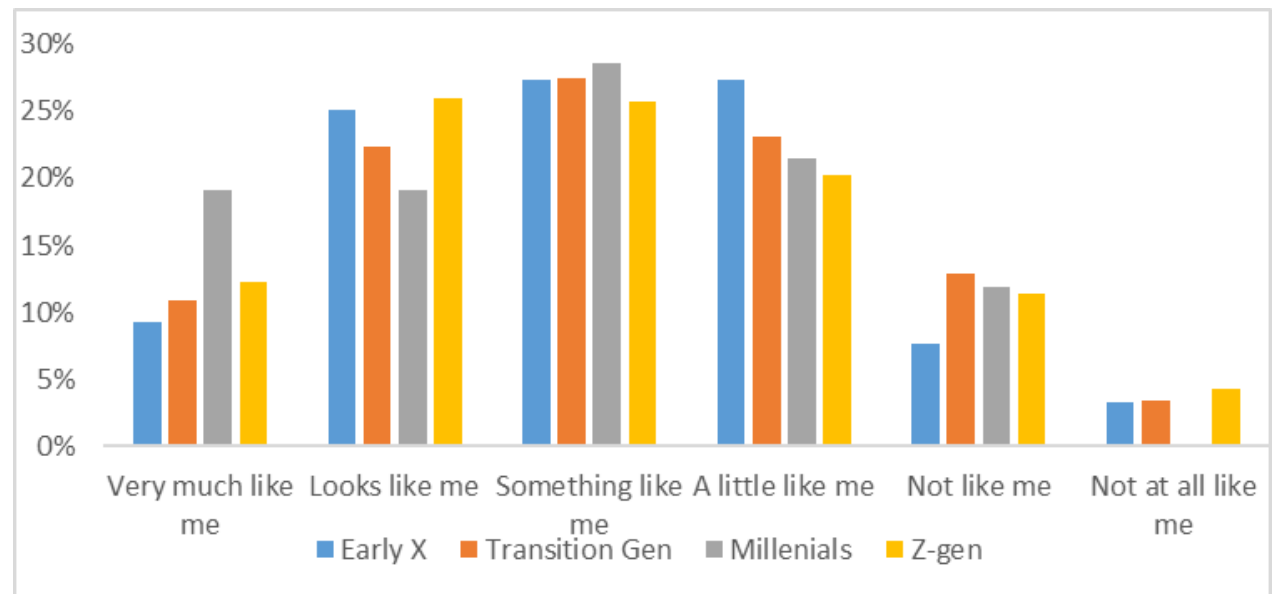

Fig. 2. For this person care for the environment and ecology is important.

It is important to say that the minority of Latvian IT professionals are neither strong environmentalists nor clear opponents of environmental concerns. But the absolute majority claim that environmental values are part of their personal value orientations. And these values do not depend on belonging to a generation.

The results of the chi-square test for two questions that tested the values of ecology and the environment disconfirm the hypothesis that these values are more typical for representatives of young generations of IT professionals in Latvia. There are no intergenerational conflicts connected with environmental consciousness that hinder sustainable development in this professional group. As IT professionals are one of the most modernized social groups in the Latvian society, it can be assumed that these values will spread in the society in general.

The second hypothesis of this study is related to priority of altruistic values among the younger generation of IT professionals. To test this hypothesis, the questionnaire included questions about whether the respondents had donated money to charity within the last year and whether they had worked as volunteers in any organizations.

Figure 3 shows the results of the responses to the question of whether respondents from different generations donated money to charity. From the data presented, it can be seen that approximately half of all surveyed IT professionals in Latvia, in all generations, donate money to charity from time to time. There are no differences between generations in this case. The results of the chi-square test, the significance of which is 0.959 prove it.

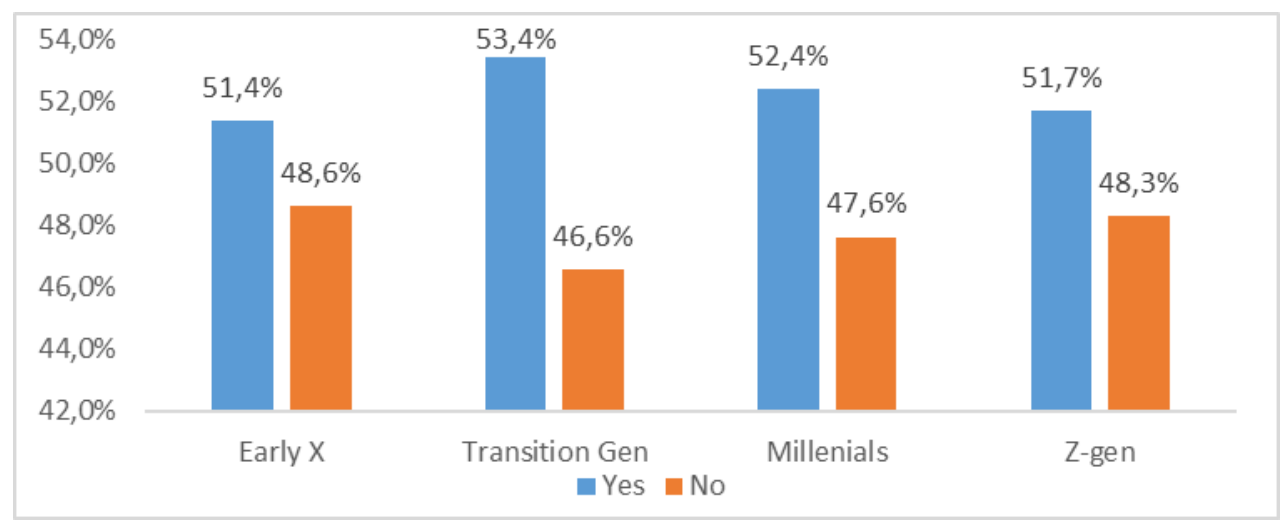

Fig. 3. Did you donate money to charity within the last year? 
Figure 4 shows distribution of the responses to the question of whether the respondent worked as a volunteer within the last year. These data suggest that working as a volunteer is extremely unpopular among all generations of IT professionals. And there are no generational differences here as well (the significance of the chi-square test is 0.358 ).

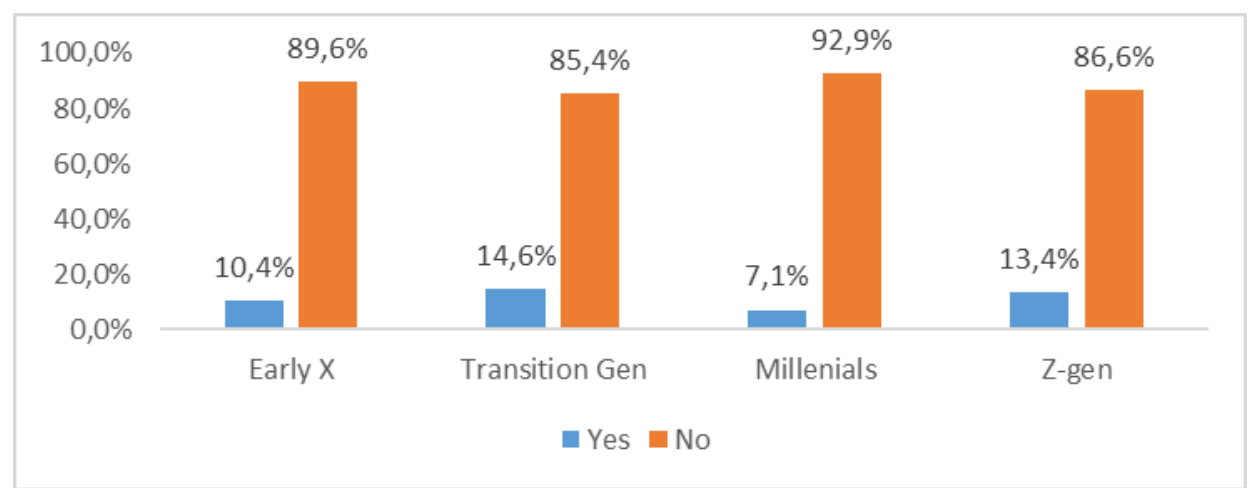

Fig. 4. Did you work as a volunteer within the last year?

Comparison of the data presented in Figure 3 and Figure 4 shows that IT professionals prefer to show their altruism in the form of financial assistance or donations rather than in the form of their own unpaid work. IT professionals in Latvia is one of the highest paid professional group. Their time costs a lot.

Absence of generational differences in the level of altruistic values among IT professionals once again confirms the conclusion that postmodern values are characteristic of the whole group, and not only for young cohorts. Value consensus and prevalence of altruistic values in society also work for sustainable development, as such development implies solidarity among members of society. Advanced value modernization of this professional group forms value orientations for the whole society.

Thus, the second hypothesis of the study, which suggest presence of contradictions between different generations of IT professionals in relation to voluntary help was also not confirmed.

Justification of offenses connected with deception of the state, such as non-payment of taxes or illegal use of benefits, can be interpreted as manifestation of dissatisfaction with the state's policy in the field of redistribution of public resources. People think that the state supports them a little, spends the country's budget in a wrong way, does not develop social sphere, etc. Intergenerational differences in justification of such offenses can be explained by the fact that, according to one generation, the state unfairly redistributes public resources in favor of other generations. To test the hypothesis about unfair redistribution of public resources among IT professionals in Latvia, the following questions were used: "Please rate on a scale from 1 to 10 , where 1 - it can never be justified, and 10 - it can always be justified

Receiving state benefits a person has no rights to.

Tax evasion.

Distribution of the respondents ' answers to these questions and differences between generations were analyzed using One-Way ANOVA Test. Figure 5 shows the answers to the question about justifying illegal use of state benefits. 


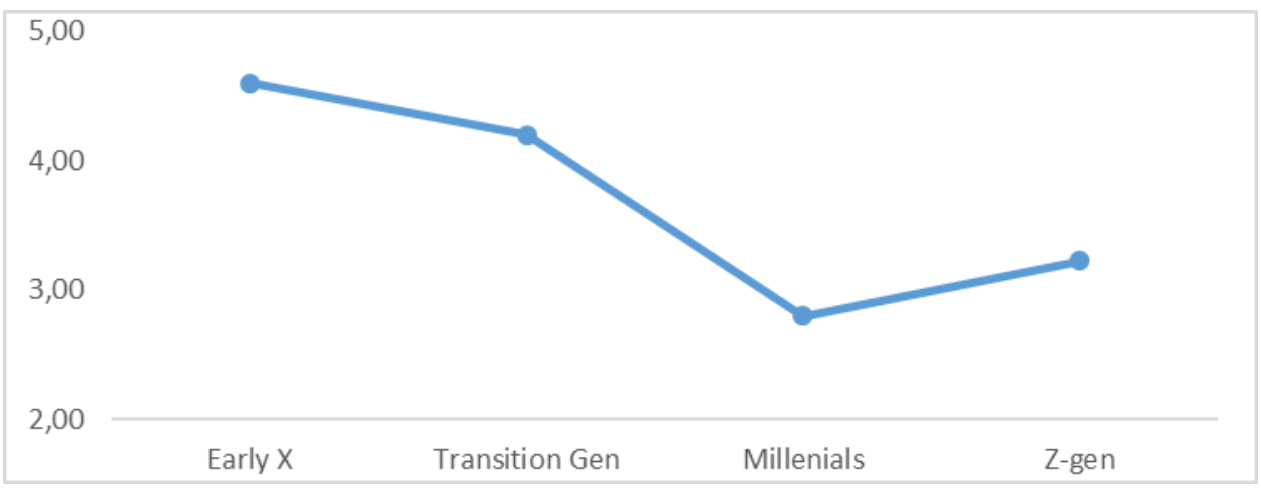

Fig. 5. Is it possible to justify receiving state benefits a person has no rights to?

The presented results show differences between generations, and the results of OneWay ANOVA Test confirm significance of these differences (the significance of the Fisher test is 0.045). Representatives of two older generations are more loyal to illegal getting of state benefits. Obviously, experience of their socialization in the Soviet era affects them.

In modern Latvian society, people aged 40 to 60 experience a double burden: they are forced to take care of their elderly parents and their children. At the same time, this generation makes the biggest contribution to the social protection system, in the form of taxes and social contributions. What's more, the state does not provide almost any support to this generation. The main beneficiaries of redistribution of public transfers are the elderly. Even taking into account payments for education, the Latvian state spends much more money on pension payments than on the younger generation. Supporting the younger generation is responsibility of parents, i.e. the generation from 40 to 60 years old. It is obvious that this situation seems unfair, and people belonging to these generations are ready to justify illegal obtaining of state benefits.

The younger generation, as a rule, has no rights for state benefits. Therefore, the younger generation is not interested in receiving them. In addition, the younger generation cannot expect to receive the same pension as today's pensioners. This violates the principles of justice. Young people respond to this by not willing to pay taxes. This result is demonstrated by the data in Figure 6, and the results of One-Way ANOVA Test confirm generational differences in this case (the significance of Fisher criterion is 0.025).

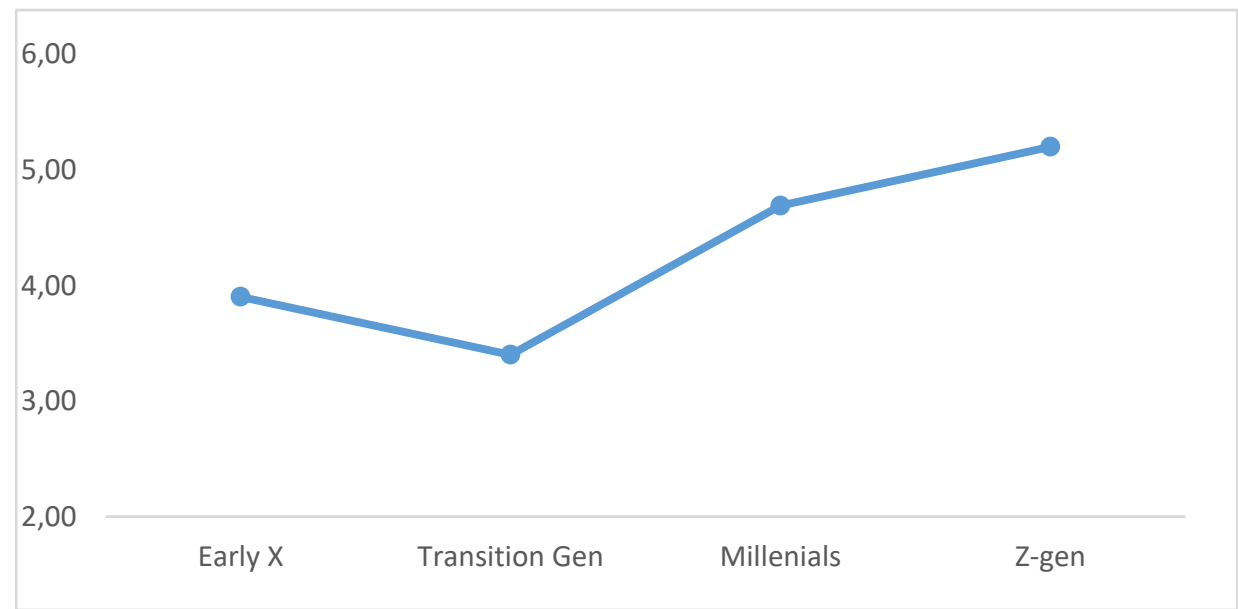

Fig. 6. Can tax evasion be justified? 
Thus, the third hypothesis of this study about generational differences in justification of offenses in relation to the state, was confirmed.

The results of the study show that there is value generational consensus in Latvian society regarding values of post-industrial society related to ecology and altruism. It can be assumed that goals of sustainable development, which assume priority of caring for the environment and mutual assistance of citizens, are shared by society. It can be considered as an important resource for sustainable development. However, social policy of the Latvian state, related to redistribution of public resources between generations, causes a sense of social injustice among citizens (at least among the most modernized social groups), which can be expressed, for example, in desire to deceive the state, not to pay taxes, etc. Lack of justice between generations violates the fundamental principle of sustainable development

\section{Discussion of the results}

The ideas of social justice between members of the same generation and between members of different generations are described in scientific literature as the main normative principles of sustainable development [17]. However, the researchers claim that political discourse on relationship between goal of fair distribution of resources and preservation of opportunity and right of future generations to quality of life is not sufficiently discussed. Is it fair to meet the needs of one generation at the expense of reducing the long-term possibilities of another generation? This is the central question in issues of intergenerational justice.

Analysis of literature on distribution of justice suggests that there are three basic principles that justify the results of public resources distribution: needs, merits (usually based on labor results), and equality (usually based on civil status). These principles work both in normative theories [18], at level of citizens ' beliefs [19, 20] and at level of social policy institutions [21-23]. Despite all differences between countries and between social groups, together they explain most of empirical results of justice distribution.

A number of studies show that inequality among age groups based on needs does not violate principles of justice [24], as people constantly change their belonging to age group throughout their lives. It is much more difficult to distribute public resources among age groups according to the principle of merit [25]. In such issues as access to health care, all societies prefer equality for age groups rather than their merits.

The use of equality principle to redistribute social resources between generations creates the least problems. However, the question of how long the state can afford to maintain the standards of equality arises.

Distribution of public resources between generations can be considered fair and honest, when each successive generation can expect the same care and benefits as the previous generation. In such a situation, financing older generations at the expense of younger generations is not problematic, as the younger generations can expect that in future they will become the object of state care. But, in the modern world, it is almost impossible [26]. This problem leads to intergenerational conflicts in Latvian society.

\section{Conclusion}

The results of the study show that in Latvian society there is a certain understanding of environmental justice, as necessity to limit intensity of consumption in order to preserve the environment. In this issue, interests of all generations intersect, so environmental problems can be solved in society without intergenerational conflicts. 
Social justice issues are more complex for Latvian society. Even in high-income social groups, generational perceptions of how fairly the state redistributes public resources differ. The younger generations understand that in future they cannot count on the same support from the state as the modern older generations. This provokes a protest, which is expressed in unwillingness to pay taxes and justification of tax evasion.

The older and middle generations, in turn, are more paternalistic, and seek to get as much as possible from the state. Therefore, they are more likely than the younger generations to justify illegal use of state benefits.

If sustainable development is the priority goal of the state, it is necessary to find new ways of making decisions that include social and environmental justice, as well as issues related to intergenerational relations, in order to take into account the values, needs and interests of all generations.

\section{References}

1. W.M. Adams, R. Aveling, D. Brockington, B. Dickson, J. Elliott, J. Hutton, D. Roe, B. Vira and W. Wolmer, Science, 306 (2004)

2. A. Attias-Donfut, S. Arber, The Myth of Generational Conflict. The family and state in ageing societie (Routledge London, New York, 2001)

3. J. K. Summers and L. M. Smith, Ambio, 43,6 (2014)

4. A. Sen, Journal of Philosophy, 103, 5 (2009)

5. A. Sen, Journal of Human Development and Capabilities, 14,1 (2013)

6. J. Thompson, Intergenerational Justice: Rights and Responsibilities in an Intergenerational Polity (Routledge New York, 2009)

7. S. Partelow, D.J. Abson, A.Fernández-Giménez, H. von Wehrden, N. Collier, International Journal of the Commons, 13, 1 (2019)

8. Global Innovation Index, (2018)

9. C. Stahl, T.S. Bridges, Integrated Environmental Assessment and Management, 9551 (2013)

10. R. Baskin, C. Sommer, Journal of the American Society on Aging, 41, 3 (2017).

11. M. Apsalone, I. Baumane-Vitolina, I. Cals, E. Šumilo, Management and Economics Review, 1, 2 (2016).

12. R. Tsosie, University of Colorado Law Review, 78 (2007).

13. A. Furlong, Youth Studies (Routledge New York, 2013).

14. D. Burstein, Fast Future: How the Millennial Generation is Shaping Our World (Beacon Press Boston, 2013).

15. J. Maantay, A. Maroko. Applied Geography 29: 111-124 (2009).

16. T. J. Erickson, Harvard Business Review, 5 (2010).

17. S. Glotzbach, S. Bauvgarner, Environmental Values, 21, 3 (2012).

18. J.E. Roemer, Intergenerational Equity and Sustainability (Palgrave, Basingstoke, Hampshire 2007)

19. F. Byskov, A. Morten, Journal of Human Development and Capabilities, 18, 1 (2017).

20. J.M. Cypher, J.L. Dietz, The Process of Economic Development (Routledge, London 2009).

21. J. Rawls, Justice as Fairness: A Restatement (Harvard University, Cambridge, MA 2001).

22. O. Lessmann, F. Rauschmayer, Journal of Human Development and Capabilities 14, 1 (2013). 
23. N. Hanley, J.F. Shogren, B. White, Environmental Economics in Theory and Practice (Palgrave, London 2006).

24. R. Mearns, A. Norton, Social dimensions of climate change: Equity and vulnerability in a warming world, (The World Bank, Washington 2010).

25. R. Balven, V. Fenters, D. Siegel, D.Waldman, Academy of Management Perspectives, 32, 1 (2018).

26. S. Gaidhani, L. Arora, B.K. Sharma, International Journal of Management, Technology and Engineering, 9, 1 (2019). 